SLAVICA BABAMOVA

National Archaeological Museum of Macedonia Skopje
UDC: $003.071(497.73 / .74) " 652 "$

904:726.825(497.73/.74)"652"

\title{
NEW INSCRIPTIONS FROM EASTERN MACEDONIA
}

\begin{abstract}
Six unpublished grave and votive inscriptions from the eastern part of the Republic of Macedonia shed new light on the epigraphic habit in this region. The importance of these epigraphic monuments is not only in the newly discovered texts, but mostly in the data they are giving on anthroponymical and prosopographical issues, which are closely connected to the history of the rich mining region in the Roman period.
\end{abstract}

\section{Probištip}

1. In the courtyard of the church St. Ilija in the village of Marčino, $4 \mathrm{~km}$ north of Probištip, there is upper part of a rectangular slab of travertine, broken at the lower part, h. 0,53 , w. 0,52 , th. 0,48 . The inscription on the front side is framed by cyma recta. H. of letters $0,04-0,03$; interlinear space $0,007-0,015$ (fig. 1).

$5 \quad \kappa \alpha i ̀ \tilde{\omega} \alpha \dot{\alpha}-$

$\delta \rho \grave{\varepsilon} \dot{\varepsilon} \alpha \tau \tilde{\eta} \varsigma$

$\dot{\alpha} \pi \mathrm{o} \tau \varepsilon \theta v \eta-$

$[\tilde{\omega}] \tau \imath$ Ov̉ $\lambda \pi i ́-$

$[\omega-----]$

Letters are square-shaped (epsilon, sigma), with rhomboid theta, omicron, and phi.

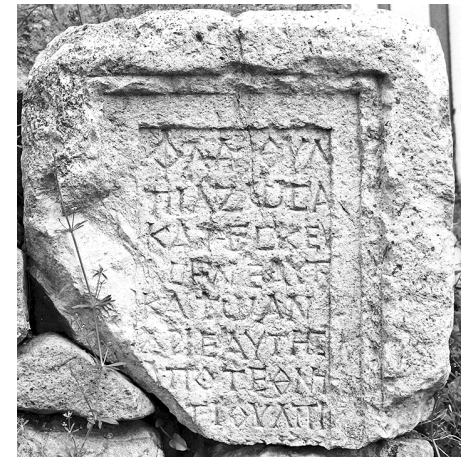

fig. 1

Ligatures: $\mathrm{TH}$ in $1.4, \mathrm{H} \Sigma$ in $1.6, \mathrm{NH}$ in 1.7.

These features direct to the dating in the second half of the $2^{\text {nd }}$ century AD. 


\section{Sveti Nikole}

2. Found at the Roman necropolis at the place called Selenovo, near the village of Gorobinci, $6 \mathrm{~km}$ west of Sveti Nikole. Lower part of a stela of white marble, $h$. 1,33 , w. 0,55 , th. 0,10 . The inscription field is framed by cyma recta. At the top of the survived part, there are traces of two pairs of feet. H. of letters $0,035-0,04$; interlinear space 0,01 (fig. 2). ${ }^{1}$

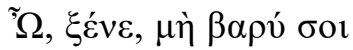

$\delta o ́ \xi \eta \pi \alpha \rho i ́ o v \tau \imath ~ \dot{\varepsilon} \pi i ́-$

$\sigma \chi \varepsilon i v \cdot \sim \dot{\varepsilon} v \theta \alpha \dot{\alpha} \delta \varepsilon$

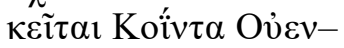

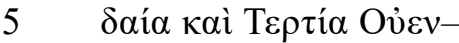

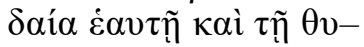

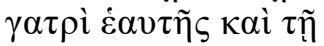

$\theta v \gamma \alpha \tau \rho 1 \delta \varepsilon \dot{\alpha} \alpha \dot{\alpha} v \varepsilon \dot{\theta} \theta \eta$

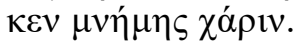

The opening metrical formula $\tilde{\omega}, \xi \dot{\varepsilon}-$

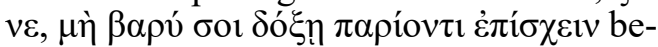
longs to one of the four known examples of this type, which are testified only in Northern Macedonia, but not in the other parts of Macedonia or throughout the Roman

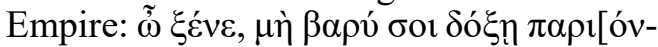

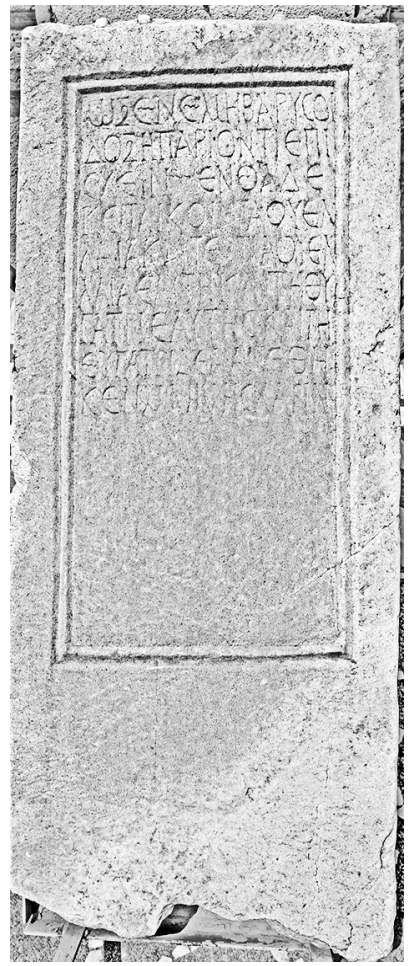

fig. 2 $\tau \alpha \ldots]$ on an anthropomorphic grave stela

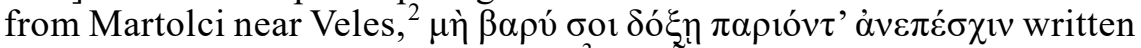

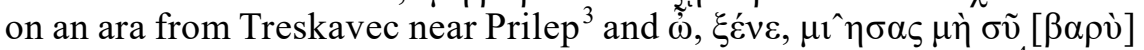

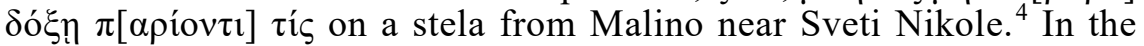
comment of the inscription from Treskavec, Papazoglu and Ricl noticed

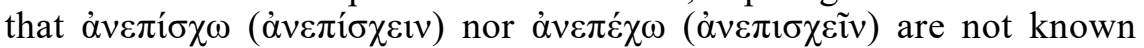
elsewhere. 'E $\pi$ í $\chi \varepsilon ı v$ on this latest inscription uses the verb غ̇ $\pi \dot{\varepsilon} \chi \omega$ (or $\dot{\varepsilon} \pi \dot{\sigma} \sigma(\omega)$.

The inscription is completely preserved, but obviously the grave stela had an upper part with a relief, regarding the traces of the feet at the broken edge, which puts it typologically into the group of stelae with developed structure, i.e. probably a triangle fronton, a relief field and an inscription field. They are usual and frequently found in Macedonia, as

${ }^{1}$ I thank archaeologists V. Atanasov and A. Nacev for their support to publish this inscription.

${ }^{2}$ Н. Вулић, Споменик 7I, I93I, 76.

${ }^{3}$ IG X, 2, 2, I, 234.

${ }^{4}$ С. Бабамова, Нови антички натписи од Македонија, ЖА Монографии 10, 20I2, 34-36 n. 13. 
in the Mediterranean culture as a whole, but in this particular case the difference between this one and other pieces with the same formula is important. Stelae from Martolci and Malino were produced of local stones with low artistic quality. Moreover, the anthropomorphic stela from Martolci belongs to the group of stelae which were found only in the mountain region which oversees the Pelagonian plain, as defined by F. Papazoglou, ${ }^{5}$ which makes them unique and typical for this region.

The text continues with the name of the deceased Quinta Vendaia and the name of her mother Tertia Vendaia, who erected the monument for herself also and for her granddaughter. The owners of the tomb have Roman naming formulas. The relation between Quinta and Tertia Vendaiae looks as they were sisters at the first sight regarding their names, but this is not particularly marked in the text, so the supposition that they were mother and daughter looks more probable. This is the unique

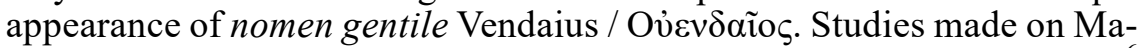
cedonian anthroponomy in Roman times notice dozens of such gentiles. ${ }^{6}$ Personal names used on other inscriptions with the same opening metrical formula use names such as Antigone, Mestylas, Paramonos, Memmia and Alexandros. The importance of the stela from Selenovo is emphasized by the fact that Roman inhabitants use a grave formula which is typical only for northern Macedonian regions among domestic population. This is the reason to count this stela among the indicators of the mixture of the traditional autochthonic marks in the grave formulas among the inhabitants who were Romans, as a part of the process of two sided influences made by Romans and the autochthonic population with a low level of Romanization in Upper Macedonia.

Letters are elongated and oval. The absence of ligatures, as well as the dating of other inscriptions with the same formula refers to the $2^{\text {nd }}$ century AD.

\section{Štip}

3. In the collection of the Institute and Museum in Štip, there is a fragment of a plaque of marble of unknown provenance, h. 0,38 , w. 0,38 , th. 0,10 . It is broken at all sides, except the left one. At the top of the fragment, there are two lines of a grave inscription. In the lower zone, in the middle, there is a depiction of upper part of a naked male figure, who was probably lying on a kline. His head is turned to the left, his right hand is shorn, proba-

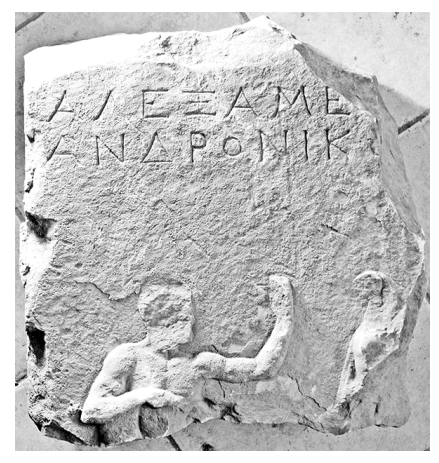

fig. 3

${ }^{5}$ F. Papazoglou, Stèles anthropomorphes et amorphes de Pélagonie, ЖA 27/1, I977, I37.

${ }^{6}$ A. Tataki, The Nomina of Macedonia, Roman Onomastics in the Greek East:

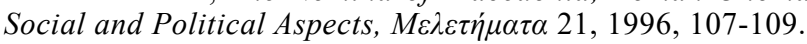


bly on the buttress of the kline, and his left hand is raised, bent in his elbow and it seems as he was holding some object, which is now broken. On the right side, there is possibly a female figure, now very damaged. H. of letters $0,025-0,03$ (o in 1. 2: 0,015); interlinear space 0,01-0,02 (fig. 3). ${ }^{7}$

\section{$A \lambda \varepsilon \xi \dot{\alpha} \mu \varepsilon[v o c]$

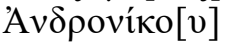

The inscription and the depiction in the relief refer to the grave stela with a scene of feasting. Concerning the inscription, the dating should be set into the late Hellenistic times, according to the grave formula made of a personal name and a patronymic in genitive and that defines this inscription as the earliest one from this region.

4. An inscribed pedestal of a votive statue of white marble was found in 1990 at the place called Kalajdžija, in the field owned by V. Nikolov, $1 \mathrm{~km}$ south of the village of Selce, which is about $10 \mathrm{~km}$ south of Štip. There are traces of a statue at the top and the pedestal is completely inscribed, including the lower cymation, h. 0,20 , w. 0,10 , th. 0,11 . H. of letters $0,017-0,015$; interlinear space 0,007 (fig. 4).

$$
\begin{aligned}
& \text { Aìntos } \\
& \text { 'E } \pi \text { íyovos } \\
& \chi \alpha \rho 1- \\
& \sigma \tau \eta ́ p ı[v] \text {. }
\end{aligned}
$$

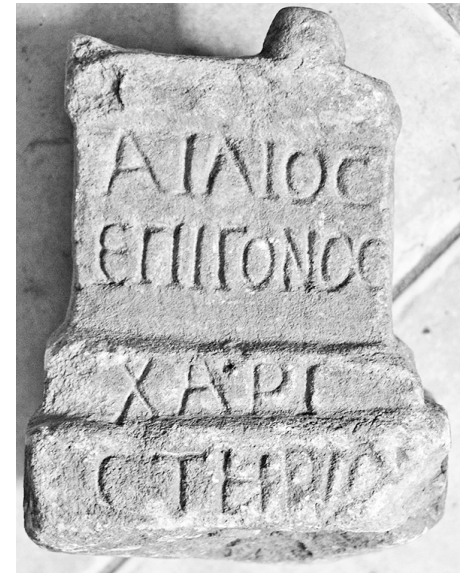

fig. 4

The letters have oval forms, no ligatures. The gentile Aelius dates the monument in the times of Hadrian or later.

The statuette was obviously a gift set in a temple, but there are no archaeological or written sources about the existence of a sanctuary in the vicinity of Selce.

5. In 2000, academician P. Hr. Ilievski gave me a photograph of a plaque made possibly of breccia (as seen on the photograph) and informed me that it was found in the vicinity of Stip. Rectangular plaque with an inscription field framed by cyma recta is broken at the upper left angle. Dimensions are unknown (fig. 5).

$[\mathrm{D}($ is $)] \mathrm{M}$ (anibus)

Iuliae Flaviae

${ }^{7}$ Inscriptions nos. 3 and 4 are published here due to the kindness of M. Šterjov, director of the Institute and Museum in Štip. 


\section{rarissimae \\ Fl(aviae) Ama[bili?] \\ $5 \quad \mathrm{M}$ (arcus) Ulp(ius) V[-- ]!̣N \\ AN(V)SS [-- - ]N \\ $\mathrm{p}$ [osuit de su?]is \\ c o n i u g i \\ bene [mere]nti.}

The cognomen of Marcus Ulpius was most probably written in 1.5 and possibly at the beginning of 1.6 , if we suppose that $A N(V) S$ at the beginning of the line are cut for the ending -anus.

The letters are shallowly cut and additionally highly damaged at some points, so 11. 6-7 are almost illegible. Ligatures: AE (bis) in 1. 2, MA in 1. 3. According to the grave formula, the inscription is to be dated in the $2^{\text {nd }} \mathrm{c}^{8}$

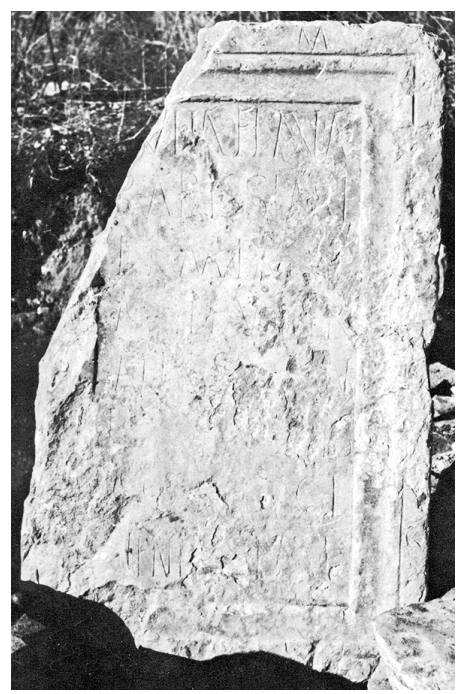

fig. 5

\section{Radoviš}

6. Found in the village of Dedino, $11 \mathrm{~km}$ south of Radoviš, an ara probably made of white marble is known by the photograph given by $T$. Nacev. The inscription is cut on the upper cymation, the body of the ara and also on the lower cymation. Dimensions are unknown (fig. 6).

$-------\omega \tau \varepsilon \dot{\varepsilon} \kappa \nu \alpha \mathrm{TI}[--]$

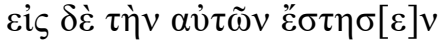

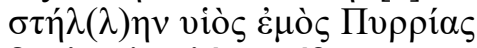

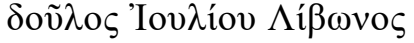

5 ő $\kappa \dot{\varepsilon} \dot{\varepsilon} \tau \varepsilon v ́[\xi \varepsilon v] \tau o ̀ v ~ \sigma v v-$ ó $\mu \alpha \mu$ ov $\kappa[\alpha i ̀ \mathrm{~K} \lambda \varepsilon] \omega v v ́ \mu \mathrm{o}[\mathrm{v}]$ $\pi \alpha \tau \rho$ ò $\varsigma \dot{\varepsilon} \alpha v \tau \tilde{\omega} v \alpha u ̛ \tau o ̀ v$

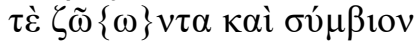

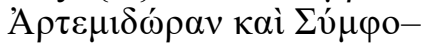

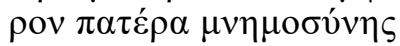

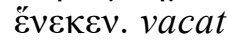
vacat $\tau$ $\alpha$ $\tilde{v}$

$\tau$
$\alpha$

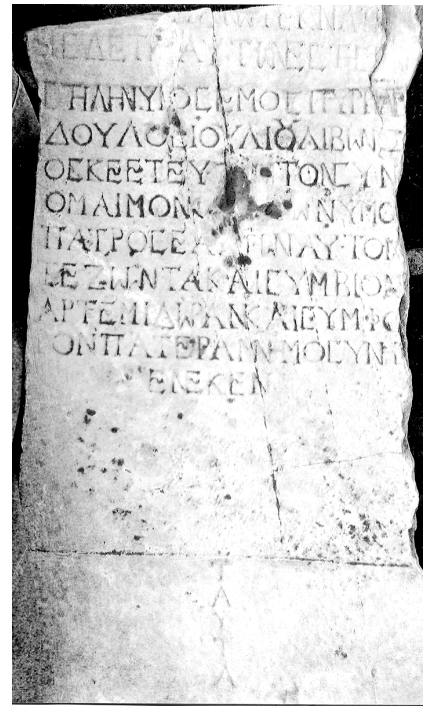

fig. 6

${ }^{8}$ С. Ферјанчић, Насељавање легијских ветерана у балканским провинцијама I-III век н.е., Београд, 2002, 233-234. 
Square epsilon and sigma. Ligatures: $\mathrm{HN}, \Omega \mathrm{NE}, \mathrm{TH} \Sigma$ in 1. 2, TH, $\mathrm{HN}$ in $1.3, \mathrm{OY}, \Omega \mathrm{N}, \mathrm{O} \Sigma$ in $1.4, \mathrm{~N} \Sigma$ in $1.5, \mathrm{NK}$ in $1.6, \Omega \Omega \mathrm{N}$ in $1.8, \Omega \mathrm{P}$, NK in 1. 9, MNHM, NH $\Sigma$ in 1. 10, NE in 1. 11. According to these features, the dating of the monument should not be earlier than the second half of the $2^{\text {nd }}$ century or beginning of the $3^{\text {rd }}$ century, although there are not many inscriptions from this region, which would confirm this dating.

Inscriptions nos. 1, 4, 5 and 6 have Imperial nomina gentilicia. Concerning the fact that their find-spots are in the region full of mines, the first impression is that they were connected with ancient metalla in different ways.

The village of Dedino is located in the mining region of Bučim (copper, gold and silver) and Damian (iron). Among other peculiarities of this inscription (no. 6), the name of Iulius Libon arises special interest. Pyrrias at this family tombstone is particularly defined as his slave, which, without any other description for Iulius Libon, looks as he was a very well-known person. The senatorial family of Libonii had their latifundia and villae in the region of Scupi and Kumanovo, where they were also working on the silver mine, which is epigraphically attested. As the inscription from Dedino is dated in the second half of the $2^{\text {nd }}$ century, it directs to the opinion that in that period Iulii and Libonii were connected with familial relationship and that they have worked together in the silver and golden mines in the vicinity of Radoviš, as they were connected with Rufrii and Ennii in the province of Moesia Superior. ${ }^{9}$

Iulius is the most frequent nomen gentile in Macedonia,$^{10}$ and it shows that during the Principate and in the first half of the $1^{\text {st }}$ century immigration of Romans was very intensive in the whole province of Macedonia and that at the same time the process of granting Roman citizenship to the local aristocracy was ongoing. The presence of Iulii in our region is most probably due to the exploitation of mines. Continual presence of Iulii (or their local successors, domestic prominent people or freedmen) is attested also by the name of Iulia Flavia in the vicinity of Štip (no. 5). Although we miss possible relations between Iulia Flavia, Flavia Amabilis(?) and Marcus Ulpius due to the hard damage of 1.6 of the inscription, their cognomina testify the presence of Roman citizens among the Greek speaking population. Aelius Epigonos (no. 4) was obviously granted Roman citizenship in the times of Hadrian or later.

Flavia Ulpia and her husband Ulpius - - - (no. 1) were Roman citizens, but their origin is impossible to be reconstructed by the remained part of the inscription. The village of Marčino lies in the closest area of Zletovo (lead and zinc) and Plavica (gold) mines and so does the town at the village of Konjuh. There are two more unpublished inscriptions from Konjuh mentioning the gens of Iulii: the grave stela of Lucius Iulius Epaphroditus erected by his sister Iulia Prima and his

\footnotetext{
${ }^{9}$ S. Dušanić, Просопографске белешке о рударству у Горњој Мезији: породице имућних досељеника на рудничком тлу, Старинар LVI, 2006, 95-98.

${ }^{10}$ A. Tataki, The Nomina of Macedonia, Roman Onomastics in the Greek East:

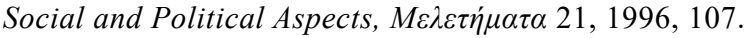


brother Iulius Classicus, dated in the $2^{\text {nd }}$ century and a fragment of a grave stela dated in the second half of the $2^{\text {nd }}$ century. Both of them, although fragmented and hardly legible, confirm that according to the cognomina, all of the deceased were local inhabitants who were part of the local aristocracy, having Iulii as their patrons. Immigrations of other Iulii and Flavii in the vicinity of Konjuh are attested by Flavius P[roculus] or Iustinianus, ${ }^{11}$ and on inscriptions from the village of Filipovci: Iulius Mucianus and Flavia Secundina. ${ }^{12}$

No direct data about the offices in the mines is given on the inscriptions, but following the presence of the most distinguished Roman gentes during the $1^{\text {st }}$ and the $2^{\text {nd }}$ centuries, it refers to the conclusion that their presence and possible migrations were usual and numerous. ${ }^{13} \mathrm{Un}-$ fortunately, there are not enough options for precise dating, because gentilicia are used only as terminus post quem, and paleographical analysis is not confident enough, because there are not many inscriptions for analogies from the region.

The region which is a subject of our interest here is extremely rarely mentioned by ancient authors. Livy conveys that after Aemilius Paulus has conquered Macedonia in 167 BC, Romans divided the land into four merides and, among other sanctions, they prohibited the exploitation of golden and silver mines, and left the iron and copper mines free for the local population. ${ }^{14}$ The region was surely preferential for the Romans in the times when the province of Macedonia was formed. According to the epigraphic sources, the utilization of the golden mine at Plavica and the silver mines in the region of Kumanovo, were in the hands of the powerful senatorial gentes. The region was in the borders of the province of Macedonia during the Republican period, before Dardania was included in the province of Upper Moesia in the first years of the $1^{\text {st }}$ century. Putting strict and precise border lines during the early Roman rule between the provinces is still an open question. Regarding these latest epigraphic monuments, after the formation of Upper Moesia, the exploitation of the metalla and the commerce connected to them were still under Roman nobility with partial involving of the local inhabitants.

The eastern part of Northern Macedonia, according to the given inscriptions, was not excluded from any political, economic, commercial and social processes of the Balkan provinces, as was usually considered in previous studies of the region, mostly due to the lack of epigraphic sources.

${ }^{11}$ IMS VI, 235 .

12 А. Керамитчиев, Новооткриени епиграфски споменици од Кратовско, ЖА 23, I973, I47-I49.

${ }^{13}$ As S. Dušanić, Просопографске белешке о рударству у Горњој Мезији: породице имућних досељеника на рудничком тлу, Старинар LVI, 2006, 85 implies they were not spending a long time in the mining regions as their place of living.

${ }^{14}$ Liv. XLV, 29, II. 


\section{BIBLIOGRAPHY}

С. Душанић, Просопографске белешке о рударству у Горњој Мезији: породице имућних досељеника на рудничком тлу, Старинар LVI, 2006, 85-102.

IMS VI: Inscriptions de la Mésie Supérieure, vol. VI: Scupi et la région de Kumanovo, par B. Dragojević-Josifovska sous la direction de F. Papazoglou, Beograd, 1982.

IG X 2, 2, 1: Inscriptiones Graecae X 2, 2 (ediderunt F. Papazoglu, M. Milin, M. Ricl adiuvante K. Haloff), Berlin, 1999.

А. Керамитчиев, Нови епиграфски споменици од Источна Македонија, ЖА 15/1, 1965, 109-115.

А. Керамитчиев, Новооткриени епиграфски споменици во Кратовско, ЖА 23/1, 1973, 147-154.

F. Papazoglou, Stèles anthropomorphes et amorphes de Pélagonie, ЖA 27/1, 1977, 135150 .

\section{РЕЗИМЕ}

Новите епиграфски споменици кои се објавени овде, покрај тоа што ја збогатуваат бројката натписи од римско време кои потекнуваат од источниот дел на Република Македонија, носат значајни податоци за регионот кој според бројот на натписи значително отстапува во однос на другите македонски области.

Натписот на споменикот (бр. 2) најден на римската некропола „Селеново“ близу с. Горобинци, Светиниколско, започнува во метричката фор-

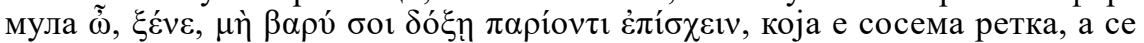
сретнува на надгробна ара од Трескавец, Прилепско, с. Мартолци, Велешко и с. Малино, Светиниколско. Од особено значење е тоа што надгробната стела од с. Мартолци е антропоморфна и припаѓa на уникатна група надгробни споменици од Пелагонија, проучена и дефинирана од Ф. Папазоглу, и носи автохтони белези. Покојничката на стелата од Селеново и нејзината мајка се римски граѓанки, па на овој начин е убаво отсликано мешањето на влијанијата меѓу домашното население и дојденците.

Од околината на Штип потекнува првиот надгробен натпис (бр. 3) регистриран во источниот дел на Република Македонија кој се датира во доцното хеленистичко време. Надгробната формула е сосема едноставна, составена од лично име и патронимик во генитив, што е типично за сите надгробни споменици од тоа време.

Натписите бр. 1, 4, 5 и 6 содржат царски гентилни имиња и со тоа укажуваат на миграции од италско тло, кои сигурно се случувале поради експлоатацијата на рудниците во регионот на Кумановско, Кратовско и Радовишко. Носителите на епиграфските споменици објавени погоре не наведуваат свои функции поврзани со рудниците, но јасно е дека станува збор за ослободеници или клиенти на римскиот нобилитет и припадници на локалната аристократија, кои од самото основање на провинцијата Македонија ги користеле бројните рудници. Нов податок дава натписот од с. Дедино (бр. 6), сместено меѓу рудниците Бучим и Дамјан, на кој се споменува Јулиј Либон(иј), кој потекнувал од фамилијата Либонии, добро епиграфски документирани како корисници на рудниците за сребро во скопско-кумановската област. 